\title{
CLINICAL AND PATHOGENETIC ANALYSIS OF COMPRESSIVE-ISCHEMIC LUMBOSACRAL RADICULOPATHY
}

\author{
*Prof. E.M. MIRJURAYEV, Ch.B. MAMATKHANOVA \\ Tashkent Institute of Postgraduate Medical Education, Department of Neurorehabilitation and \\ Oriental Medicine, Tashkent, Uzbekistan
}

Key words: radiculopathy, spinal nerve, compressive injure of roots.

Introduction. Lumbosacral radiculopathies are frequently observed disorders of spinal nerves (SN) of vertebral cause per their location. Available scientific data shows that $70 \%$ of all damages of $\mathrm{CN}$ roots of vertebral origin are seen at this part of spine $[1,2,3.6,11]$. Lumbar pain syndrome developing as a result of discoradicular conflict (DRC) or of vertebral origin is one of the main causes of disability among population of young and adult ages. Treatment of manifestations of DRC and their rehabilitation is a time-consuming, labor-intense, and costly process, requiring large resources $[4,5,8$, $9,10]$. Compressive injury of $\mathrm{CN}$ roots is the most severe and durable manifestation of DRC, which is considered a mixed pathology of neurology and neurosurgery. Considering clinical significance of this issue, we conducted a detailed analysis of compressive damage of lumbar $\mathrm{CN}$ of disc- and verte- bral origin.

Materials and Methods: 120 patients, consisting of 50 females and 70 males were examined. Patients were enrolled into the study using casecontrol principle. Mean age of patients was $45 \pm 15.6$ years. In addition to neurologic and somatic evaluation, instrumental examination was also conducted, including MRI or CT of lumbar section of vertebral column. The following disorders were identified as etiologic factors for $\mathrm{CN}$ damage: 1. Protrusions and hernias of intervertebral discs; 2. osteophytes of posterior longitudinal ligament (PLL); 3. hypertrophy of yellow ligament (ligamentum flavum); and 4. displacement of vertebral body.

Etiologic factors of DRC are presented in the following Table 1, with lateralization and gender differences.

Table 1

Etiologic factors of radiculopathy with lateralization and gender demorphism

\begin{tabular}{|l|l|l|l|l|}
\hline & Males $(\Pi=70)$ & \multicolumn{3}{l|}{ Females $(\Pi=50)$} \\
\hline Lateralization & Right & Left & Right & Left \\
\hline Disc protrusions and hernias & $26(37 \%)$ & $18(26 \%)$ & $16(32 \%)$ & $14(28 \%)$ \\
\hline Osteophytes of PLL & $9(13 \%)$ & $5(7 \%)$ & $5(10 \%)$ & $4(8 \%)$ \\
\hline YL hypertrophy & $3(4 \%)$ & $2(3 \%)$ & $4(8 \%)$ & $2(4 \%)$ \\
\hline Vertebral displacement & $2(3 \%)$ & $2(3 \%)$ & $2(4 \%)$ & $1(2 \%)$ \\
\hline Other causes & $2(3 \%)$ & $1(1,5 \%)$ & $1(2 \%)$ & $1(2 \%)$ \\
\hline Total & $42(60 \%)$ & $28(40 \%)$ & $28(56 \%)$ & $22(44 \%)$ \\
\hline
\end{tabular}

Study Results. As seen from the table, disc protrusions and hernias in both male and female patients are the primary cause of compression of $\mathrm{CN}$ roots $(63 \%$ and $46 \%$, respectively). Regardless of gender differences, right-sided lateralization of the damage is always prevailing. Further, osteophytes of PLL are the second cause of $\mathrm{CN}$ root damage based on their incidence $(20 \%$ and $18 \%$ in males and females, respectively. Again, as demonstrated in the table, right-sided damage prevails in osteophytes as well. Hypertrophy of yellow ligament and displacement of vertebral body as the cause of radiculopathy have about the same distribution for lateralization both in males and females. However, these factors had two-times higher significance in females compared to males. Additionally, in females hypertrophy of YL coincides with manifestations of spinal venous stasis. The followings were identified by ourselves as additional causes or factors resulting in radiculopathy: osteoporotic spondylopathy, ver-

*e-mail: emmir@bk.ru 
tebral body fractures, sacralization of lumbar vertebrae. In both study groups their frequency was $1.5-3 \%$.
Incidence of root damages based on their localization and clinical symptomatology are provided in Table 2 .

Table 2

Incidence, lateralization, and clinical symptomatology of spinal nerve roots

\begin{tabular}{|l|l|l|l|l|l|l|}
\hline & \multicolumn{3}{|l|}{ Males $(\Pi=70)$} & \multicolumn{2}{l|}{ Females $(\Pi=50)$} & Symptoms \\
\hline Root & Right & Left & Right & Left & Motor tonic & Sensory, pain \\
\hline L 1 & $1(1,5 \%)$ & - & - & - & & $*$ \\
\hline L 2 & $1(1,5 \%)$ & $1(1,5 \%)$ & $1(2 \%)$ & - & & $*$ \\
\hline L 3 & $3(4 \%)$ & $1(1,5 \%)$ & $1(2 \%)$ & $1(2 \%)$ & $*$ & $*$ \\
\hline L 4 & $8(11 \%)$ & $5(7 \%)$ & $6(12 \%)$ & $4(8 \%)$ & $* *$ & $* *$ \\
\hline L 5 & $23(33 \%)$ & $16(23 \%)$ & $15(30 \%)$ & $12(24 \%)$ & $* * *$ & $* *$ \\
\hline S 1 & $5(7 \%)$ & $4(6 \%)$ & $5(10 \%)$ & $4(8 \%)$ & $*$ & $*$ \\
\hline S 2 & $1(1,5 \%)$ & $1(1,5 \%)$ & - & $1(2 \%)$ & $*$ & $*$ \\
\hline Total & $42(60 \%)$ & $28(40 \%)$ & $28(56 \%)$ & $22(44 \%)$ & & \\
\hline
\end{tabular}

As seen from the table above, right-sided L5 root damage was most frequently identified among males (56\%) and females (54\%). Clinical symptomatology was characterized by decline in sensitivity on relevant (stripe-type) and paresis of extensor muscles of hallux. Spastic contraction of tibial muscles (cramps) primarily seen in peroneal group of muscles is another frequent symptom. Pain sensation was noted on antero-lateral surface of hips and lumbosacral section of spine.

Second place was occupied by L4 root, based on frequency, which was also observed on right side $(18 \%$ and $20 \%$ among males and females, respectively). Compression of L4 root presented with decrease and/or loss of patellar reflex, decrease of sensation on relevant dermatome, and in rare cases with weakness of extensor function of quadriceps muscle of thigh. Pain irradiated to antero-lateral surface of thighs and sacral site. Some of the patients had cramps in tibial muscles.

S1 root was at third place based on frequency of reports. It should be noted that mechanism of damage in this root is slightly different than other CN. Here, nerve root is damaged in spinal canal on the level of L5 vertebra and respective intervertebral disc. Presence of medial disc hernia, hypertrophy of yellow ligament, and displacement of L5 vertebra towards sacral bone may be shown among predisposing factors of S1 root damage within spinal canal. Clinically, these patients had gluteal and sacral pain, hypesthesia of lateral side of foot and little finger. There were reports of decline or loss of Achill's reflex. Slight movement disorders presented with weakness of the following muscles: long flexor muscles of feet, biceps muscle of thigh and gastrocnemius muscle.

L3 root damage is at fourth place probably due to higher outlet point and less functional importance of the current motor spinal segment (in comparison with segments located below). Damage of this root is seen 1.5 times more in males than in females $(5.5 \%$ versus $4 \%)$. Although, the damage is mostly identified on right side in males, our study found that in females damage of the root on both sides is equally prevalent. Patients with L3 root damage complained of pain on anterior surface of thighs and medial side of knee joint. Muscle weakness was not identified, except rare cases when patients complained of weakness in legs while climbing up stairs or walking for a long time with a load. However, strengthening or weakening of patellar reflex on injured side was also observed.

Isolated entrapment of L2 and S2 nerve roots were seen in sporadic cases both among males and females (3\% and $2 \%$, respectively) and were caused by serious diffuse and degenerative vertebral affection, such as spondylopathy and spondylosis. Clinical picture of L2 radiculopathy consisted of pain on anterior surface of thighs and inguinal site, decrease of sensation on relevant dermatome. Weakening of patellar reflex and loss of cremasteric reflex were noted in male 
patients. S2 radiculopathies were characterized by sensation of numbness on posterior surface of thigh and perineal area. Achill's reflex was absence. Also, all patients had dysuric complaints in form of urine incontinence.

L1 root damage had a sporadic nature and was identified in one male patient only. Pathologic fracture of first lumbar vertebra due to osteopathic spondylosis was the causative factor of such damage. Patient complained of pain on lateral side of abdominal wall and inguinal area. No movement disorders were identified.

Conclusions. Obtained data allows assuming the followings: clinical presentation of radicu-

\section{REFERENCES}

1. Дривотинов Б. В., Бань Д. О. Мануальная терапия при неврологических проявлениях поясничного остеохондроза (литературное обозрение) //Медицинский журнал. - 2006. -№1. - С. 19-22.

2. Епифанов В.А., Епифанов А.В. Остеохондроз позвоночника (диагностика, лечение, профилактика). М. МЕДпресс-информ 2008.

3. Кузьминов К. О. Клинико-ультрасонографическая диагностика рефлекторных компрессионных синдромов поясничного остеохондроза: Автореф. дис. ... канд. мед. наук. - М., 2002. - 19 с.

4. Олешкевич Ф. В., Сакович И. И., Федулов А. С. Опыт использования нейрохирургического лазера при удалении грыж межпозвонковых дисков // Журнал теоретической и клинической медицины. - 2000. - №3. - С. 140-141.

5. Скоромец А. А., Скоромец Т. А., Шумилина А. 11. Остеохондроз дисков позвоночника // Неврологический журнал. - 2003. - № 1. - С. 59-69. lopathies of lumbosacral localization consist of sensor and motor changes. Descending list of root damage based on their incidence is as follows: L5, L4, S1, and L3 roots, further rarely and equally L2 and S2, only sporadically L1. Severity of root damage depends on functional importance of relevant root. S1 and S2 radiculopathies may occur due to involvement of cauda equina on Lv level or higher.

Osteophytes of PLL, hypertrophy of YL, and displacement of vertebral bodies with compression of dural sac and structures of cauda equina may serve as etiologic factors of spinal nerve damage along with intervertebral disc hernias.

6. Черненко О. А. Лечение болевых скелетно-мьппечных поясничных синдромов // РМЖ. - 2000. - Том 8, № 10. - C. 408-410.

7. Шостак Н. А.,Современњые подходы к терапии боли в нижней части спины// Consilium medicum. -2005.T.5,№8-c.457-459

8. Sei Y. Multiple effects of caffeine on $\mathrm{Ca} 2 \sim \mathrm{t}-$ release and influx in human B lymphocytes / Y. Sei, K. Gallagher, J. W. Daly // Cell. Calcium. - 2001. - Vol.29. - P. 149-160.

9. Van Tulder M. W., Becker A., Bekkering T. European guidelines for the management of acute nonspecific low back pain in primary care. - 2004.

10. Veresciagina K.. Ambrozaitis K.V., Spakauskas B. Health-related quality of-life assessment in patients with low back pain using SF-36 questionnaire. Kaunas: Medicine 2007; 43; 8: 607-613.

11. Woolf C., Mannion R. Neuropathic pain: aetiology, symptoms, mechanisms and management. Lancet 2001; 357: Suppl: 1959-1964.

\title{
РЕЗЮМЕ
}

\section{КЛИНИЧЕСКИЙ И ПАТОГЕНЕТИЧЕСКИЙ АНАЛИЗ КОМПРЕССИОННО-ИШЕМИЧЕСКИХ ПОЯСНИЧНО-КРЕСТЦОВЫХ РАДИКУЛОПАТИЙ}

\author{
Проф. Э.М.МИРДЖУРАЕВ., Ч.Б. МАМАТХОНОВА \\ Ташкентский институт усовершенствования врачей, Кафедра "Нейрореабилитаџии с курсом \\ восточной медицины", Ташкент, Узбекистан
}

Пояснично-крестцовые радикулопатии, это наиболее часто наблюдаемые по локализации вертеброгенные поражения спинномозговых нервов. Поясничный болевой синдром, возникающий на фоне диско-радикулярного конфликта (ДРК), или вертеброгенной этологии, является основной причиной утраты трудоспособности лиц молодого и зрелого возраста. В исследование было обследовано 120 
пациентов различного пола: 50 случаев составили лица женского пола и 70 - мужского. Пациенты были включены в исследования по принципу случай-отбор. Полученные данные позволяют сделать следующие выводы: клинические проявления радикулопатий пояснично-крестцовой локализации складываются из чувствительных и двигательных нарушений. По убывающей частоте поражения наблюдается следующий порядок: корешки L5, L4, S1, L3, затем редко и равнозначно L2 и S2, и только спорадически - L1 корешок. Степень проявления корешковых нарушений зависит от функционального значения корешка. Радикулопатии S1 и S2 могут наступить при поражении конского хвоста на уровне позвонка L5 и выше. Кроме грыж межпозвонковых дисков, факторам поражения спинальных нервов могут выступать остеофиты задней продольной связки, гипертрофия желтой связки и смещения тел позвонков с компрессией дурального мешка и образований конского хвоста.

Ключевые слова: радикулопатия, спинальный нерв, компрессионные поражения спинальных корешков.

\title{
XÜLASə
}

\section{KOMPRESSIOON-İŞEMİK BEL-OMA RADİKULOPATIYYLARININ KLINIK Və PATOGENETIK ANALIZI}

\author{
Prof. E.M.Mircurayev, Ç.B.Mamatxonova \\ Daşkənd Həkimlari Təkmilləşdirmə İnstitutu, Şərq təbabəti kursu ila neyroreabilitasiya kafedrası, \\ Daşkənd, Özbəkistan
}

Bel-oma radikulopatiyaları onurğa beyni sinirlərinin lokalizasiyasına görə ən çox rast gəlinən vertebrogen zədələnmələridir. Həm cavan, həm də yaşlı dövrdə disk-radikulyar konflikt və ya vertebrogen etiologiyalı bel ağrıları əmək qabiliyyətinin itirilməsinin əsas səbəblərindəndir. Tədqiqatımızda 120 xəstə iştirak etmişdir: bunlardan 50 qadın və 70 kişi olmuşdur. Xəstələr tədqiqata hadisə-seçim prinsipinə əsasən cəlb edilmişdirlər. Đldə edilmiş məlumatlar aşağıdakı nəticələrə gəlməyə imkan verir: bel-oma lokalizasiyalı radikulopatiyaların klinik əlamətləri həm hissi, həm də hərəki pozulmalardan ibarət olur. Kökcüklərin zədələnməsinin azalan s1rada rast gəlinmə tezliyi belə olmuşdur: L5, L4, S1, L3, sonra nadirhallarda və eyni tezlikdə L2 və S2, və ancaq sporadik - L1 kökcüyü. Kökcük pozulmalarının yaranma dərəcəsi kökcüyün funksional əhəmiyyətindən asılıdır. S1 və S2 radikulopatiyaları L5 fəqərəsi və daha yuxarı səviyyədə at quyruğunun zədələnməsi zamanı yarana bilər. Fəqərəarası disklərin yırtıqlarından başqa spinal sinirlərin zədələnmə səbəblərinə arxa boylama bağların osteofitləri, sarı bağın hipertrofiyası və at quyruğu törəmələrini və dural kisəni kompressiya edən yerini dəyişmiş (sürüşmüş) fəqərə cisimləri aid edilə bilər.

Açar sözlər: radikulopatiya, onurğa beyni siniri, spinal sinir kökcüklərinin kompression zədələnmələri.

Redaksiyaya daxil olub: 14.02.2014

Çapa tövsiyə olunub: 11.03.2014

Rəyçi: t.e.d., prof. R.K.Şiraliyeva 